\title{
Comparative Evaluation of Pre-Induction Changes in Bishop's Score with Insertion of Intra-Cervical Foley Catheter and Vaginal Misoprostol
}

\author{
Mandal $\mathbf{A}^{1}$ \\ 'Paropakar Matenity and Women's Hospital, Thapathali, Kathmandu, Nepal
}

Received: 5-Mar-2017; Accepted: 30-May-2017

Aims: The aim of this study was to compare changes in pre-induction Bishop's score with insertion of intra-cervical Foley catheter and vaginal misoprostol administration for cervical ripening.

\begin{abstract}
Methods: It is a comparative study done among 50 patients at term that had Bishop's score $<5$ in College of Medical Science in Bharatpur. Intra-cervical Foley catheter was used in half of the women and intra-vaginal insertion of 50 microgram misoprostol tablet was used in the rest. After 24 hours of post ripening, Bishop's score was noted and labour was induced with inj. oxytocin if required.
\end{abstract}

Results: Both groups showed significant changes in the mean Bishop's score after ripening agents, 7.64 and 7.25 for Foley catheter group and Misoprostol group respectively. Eighty four percent patients from Foley catheter group and $72 \%$ patient from Misoprostol had normal delivery.

Conclusions: Post ripening mean Bishop's score was significantly better in Foley catheter group as compared to Misoprostol group.The induction to labour interval, induction to delivery interval and labour to delivery interval were less in Foley's catheter group than Misoprostol group.

Keywords: cervical ripening, Foley catheter, misoprostol

DOI: 10.3126/njog.v12i2.19958

\section{INTR ODUCTION}

Labour is a physiological process during which the fetus and placenta are expelled outside of the uterus. ${ }^{1}$ There are three stages of labour. First stage of labour starts from onset of true labour pain and ends with full dilation of cervix (which has latent and active phase). Second stage of labour starts from full dilation of cervix and ends with expulsion of fetus from birth canal and third stage of labour ends with expulsion of placenta and membranes. ${ }^{2}$

Labour is preceded with biochemical changes in the connective tissue in and around the cervix with gradual effacement and dilatation of cervix as a result of rhythmic uterine contraction of sufficient frequency, intensity and duration. ${ }^{3}$ Objective assessment of the cervix preparedness is made by means of Bishop's score. The Bishop's score is used to assess the success rate before induction of labour. Bishop's score of six or more is considered favorable

\section{CORRESPONDENCE}

Dr Anju Mandal,

Paropakar Maternity and Women's Hospital, Thapathali Phone: +977- 9841208603;

Email: anju_mandal2001@yahoo.com for labor induction. It has following components like cervical dilation, effacement, consistency, position and head station. ${ }^{4}$

A number of agents are in use for accomplishment of the task and thereby improvement of Bishop's score which includes mechanical agent like Foley catheter and pharmacological agent like misoprostol. Foley's catheter causes the secretion of endogenous prostaglandins by its mechanical effect of stretching and irritating the uterine cervix which influences biochemical changes in the cervix besides mechanical pressure from the Foley balloon induces cervical dilatation. Tab misoprostol acts on the cervix which helps in ripening by changes in extracellular ground substance of the cervix. Misoprostol is found to be a reliable agent for cervical ripening. ${ }^{5}$

Adeniji et al. performed a study to compare vaginal misoprostol and Foley catheter for cervical ripening and reported that misoprostol was more effective to improve the scores of cervical length and consistency, while Foley catheter was better to improve the cervical os dilation during pre-induction cervical ripening. ${ }^{6}$ Jindal et al. reported significant reduction of induction to delivery interval (11.58 vs. 19.45 hours) in cases of the Misoprostol group as 
compared to intra-cervical Foley insertion. Eighty eight percent women delivered within 24 hours in misoprostol group in contrast to seventy two percent in intra-cervical Foley catheter group. ${ }^{7}$ Kashanian et al. observed that Foley catheter is a safe, suitable method for patient with unfavorable cervix which increases the number of delivery within 24 hours. In addition, intra-cervical Foley catheter insertion does not involve any over-activity of uterus like hyperstimulation as that of misoprostol. ${ }^{8}$

This study is done to compare the efficacy of intracervical Foley's catheter and intra-vaginal misoprostol on the improvement of Bishop's inducibility score, to find out induction to labour interval, labour to delivery interval, induction to delivery interval and complication of labour in each Foley catheter and Misoprostol group.

\section{METHODS}

It was a comparative study which was done among the women who required cervical ripening prior to the labour induction in the Department of Obstetrics and Gynecology in College of Medical Sciences Teaching Hospital (COMS-TH), Bharatpur. Ethical clearance was taken from the hospital's ethical board. A total of 50 cases were included in the study during the period of two years (1/10/2012 to 30/9/2014). All women with singleton term pregnancy, vertex presentation, Bishop's score $<5$ and without cephalopelvic disproportion were included in the study after informed written consent. Grand multipara, women with previous cesarean section / scarred uterus, multiple pregnancy, mal-presentation and medical disorders like heart disease, asthma were excluded. Women were divided into two groups, in one group intra-cervical Foley catheter insertion was done and in next group intra-vaginal administration of tablet misoprostol $(50 \mu \mathrm{g})$ was done. Women in Foley catheter group had insertion of 24 F Foley's catheter through internal os of cervix under aseptic condition and then balloon was inflated with $30 \mathrm{cc}$ of distilled water and catheter was strapped in the middle of the thigh with elastic tape without undue tension to be left for 24 hours unless expelled in between. After 24 hour, if the catheter was not expelled then the balloon was deflated and removed. Per vaginal examination was done to assess the changes in Bishop's score and recorded in the predesigned proforma. Women from Misoprostol group received tab misoprostol 50 $\mu \mathrm{g}$, in the posterior fornix every four hourly till 24 hours (maximum 6 doses). At the end of 24 hours, improvement of Bishop's score was noted and recorded in the proforma for both the groups. In the event, any of the cases from either group went into spontaneous labour, then labour was monitored with the help of Partograph. However, those cases which failed to go into spontaneous labour were subjected to medical induction using titrating dose of oxytocin till active uterine contraction appeared. Data were entered in Microsoft Office Excel Worksheet and statistical analysis was done using SPSS version 20.0. "p-value" of less than 0.05 was considered.

\section{RESULTS}

In this study, women were of 15-35 years and 25 each were studied in Foley catheter induction and Misoprostole induction group. Peak incidence was seen in 21-30 years in both groups. There were 20 and 15 cases of primigravida in Foley and Misoprostol group respectively.

At the enrollment, initial mean Bishop's score was 3.66 in Foley catheter group and 3.44 in Misoprostol group (Table-1). The mean improvement of Bishop's score after application of ripening agent in Foley group was 7.64 and Misoprostol group was 7.25 (Table-2). Improvement of Bishop's score was observed more in Foley catheter group which was statistically significant.

Table-1: Bishop's score status at enrollment

\begin{tabular}{|llcl|}
\hline & \multicolumn{2}{l|}{$\begin{array}{l}\text { Frequency by } \\
\text { Bishop's score }\end{array}$} & Remarks \\
& $\mathbf{0 - 2}$ & $\mathbf{3 - 5}$ & $\mathbf{p}=\mathbf{0 . 0 0 2}$ \\
\hline $\begin{array}{l}\text { Foley } \\
\text { catheter }\end{array}$ & 5 & 20 & $\begin{array}{l}\mathrm{N}=25, \text { mean } \\
\text { score }=3.66\end{array}$ \\
Misoprostol & 4 & 21 & $\begin{array}{l}\mathrm{N}=25, \text { mean } \\
\text { score }=3.44\end{array}$ \\
\hline
\end{tabular}

Table-2: Status of Bishop score after ripening agent

\begin{tabular}{|llcl|}
\hline & \multicolumn{2}{l}{$\begin{array}{l}\text { Frequency by } \\
\text { Bishop's score }\end{array}$} & Remarks \\
& $\mathbf{5 - 7}$ & $\mathbf{8 - 1 0}$ & $\mathbf{p}=\mathbf{0 . 0 0 2 1}$ \\
\hline Foley catheter & 11 & 14 & $\begin{array}{l}\mathrm{N}=25, \text { mean } \\
\text { score=7.64 }\end{array}$ \\
Misoprostol & 12 & 13 & $\begin{array}{l}\mathrm{N}=25, \text { mean } \\
\text { score=7.25 }\end{array}$ \\
\hline
\end{tabular}

Out of 50 women, $16(64 \%)$ women in Foley's catheter group and 15 (60\%) women in Misoprostol group needed induction of labour. The mean interval between induction to delivery was 1.32 in Foley catheter group and 1.52 in Misoprostol group which was not statistically significant (Table-3). 
Table-3: Induction to labour interval in hours

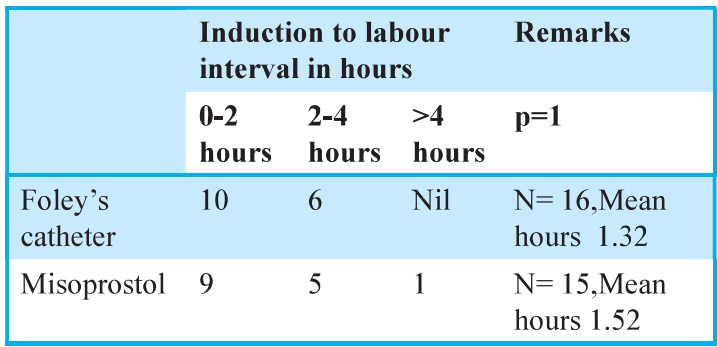

Mean of induction-delivery interval of women in Foley catheter group was 4.48 hours as compared to women in Misoprostol group which was 5 hours which was not statistically significant (Table-4).

Table-4: Induction-delivery interval among study group

\begin{tabular}{|lllllll|}
\hline & \multicolumn{3}{l}{$\begin{array}{l}\text { Induction-delivery } \\
\text { interval in hours }\end{array}$} & Remarks \\
& $\mathbf{4 - 6}$ & $\mathbf{> 6 - 8}$ & $\mathbf{> 8 - 1 0}$ & $\mathbf{> 1 0}$ & $\mathbf{p = 1}$ \\
\hline Foley catheter & 1 & 11 & 4 & Nil & $\begin{array}{l}\text { N=16, Mean } \\
\text { hours 4.48 }\end{array}$ \\
Misoprostol & 2 & 10 & 3 & Nil & $\begin{array}{l}\text { N=15,Mean } \\
\text { hours 5 }\end{array}$ \\
\hline
\end{tabular}

The total labour lasted between 4-6hours in the majority of the cases $(60 \%, n=15)$ in Foley catheter group and in Misoprostol group $(53 \%, \mathrm{n}=13)$ (Table-5). The total of 17 cases, 10 cases (40\%) in Foley catheter groupand 7 cases $(28 \%)$ in Misoprostol group required augmentation of labour with ARM (in both induced and spontaneous labour).

Table-5: Labour-delivery interval in hours

\begin{tabular}{|c|c|c|c|c|}
\hline & \multicolumn{3}{|c|}{$\begin{array}{l}\text { Labour-delivery } \\
\text { interval in hours }\end{array}$} & \multirow{2}{*}{$\begin{array}{l}\text { Remarks } \\
p=0.846\end{array}$} \\
\hline & $\begin{array}{l}\text { 4-6 } \\
\text { hours }\end{array}$ & $\begin{array}{l}>6-8 \\
\text { hours }\end{array}$ & $\begin{array}{l}>8 \\
\text { hours }\end{array}$ & \\
\hline $\begin{array}{l}\text { Foley } \\
\text { catheter }\end{array}$ & 15 & 8 & 2 & $\begin{array}{l}\text { N: } 25 \\
\text { (Mean } \\
\text { hours } \\
5.08 \text { ) }\end{array}$ \\
\hline Misoprostol & 13 & 9 & 3 & $\begin{array}{l}\text { N: } 25 \\
\text { (Mean } \\
\text { hours 6) }\end{array}$ \\
\hline
\end{tabular}

Among the women in Misoprostol group, total four cases $(16 \%)$ had complications like hypertonus $(n=1$, $4 \%)$, tachysystole $(n=2,8 \%)$ and pyrexia $(n=1,4 \%)$. None of these were seen in women in Foley's catheter group. Non-reassuring fetal heart sound was seen in one women each $(n=1,4 \%)$ in both the groups.

\section{DISCUSSION}

The mean value (3.66 in Foley catheter and 3.44 in Misoprostol group) of pre- ripening Bishop's score of this study is comparable to that of Ferdous et al (mean= 3.62 in Foley's catheter and 3.2 in Misoprostol group) and Sujata et al (mean $=3.40$ in Foley's catheter and 3.2 in Misoprostol group). ${ }^{9,10}$

In this study, post ripening Bishop's score in Foley's catheter group was slightly higher than Misoprostol group (7.64 in Foley's catheter and 7.24 in Misoprostol group). However, Adeniji et al., Sujata et al., Owolabi et al, Thakur et al., Fatemeh et al and Fekrat et al. reported higher improvement of post ripening Bishop's score in Misoprostol group than Foley's catheter group..$^{6,10-14}$ In study done by Sciscione et al. and Niromanesh $\mathrm{S}$ et al. there was no change in post ripening Bishop's score in both the group. ${ }^{15,16}$

In this study, the mean hours of induction to labour interval was less in Foley catheter group (1.32 hours) than Misoprostol group (1.54 hours). However, induction to labour interval in the study done by Ferdous et al. was more in Foley's catheter group (15.26 \pm 3.58 hours) compared to Misoprostol group (13.60 \pm 5.0 hours). ${ }^{9}$

The mean value of induction to delivery interval (4.48 hours in Foley catheter and 5 hours in Misoprostol group) of this study is similar to that of Adeniji et al. ${ }^{6}$ Induction to delivery interval was more in Foley catheter group in the study done by Ferdous et al (21.18hours in Foley catheter group and 20.04 hours in Misoprostol), Deskmukh et al (15.32 hours in Foley catheter and 14.2 hours in PGE2 gel group) and Afolabi et al. (20.03 hours in Foley catheter and 11.84 hours in misoprostol group). ${ }^{9,17,18}$ However, in the study of Culver et al., induction-delivery interval in Foley catheter was less (18hours) than in Misoprostol group (24hours). ${ }^{19}$ The duration of induction to delivery interval is longer as compared to this study as they included the phase of ripening of cervix also in the total induction period.

Ferdous et al had shorter mean labour to delivery interval in Foley catheter group (5.92 hours) compared to Misoprostol group (6.44 hours). This finding is comparable to this study (5.08 hours in Foley's catheter group, 6.0 hours in Misoprostol). ${ }^{9}$

In this study, requirement of agumentaion with ARM was more in Foley catheter group $(n=10,40 \%)$ than 
in Misoprostol group $(n=7,28 \%)$. However, the study done by Ferdous et al had higher incidence of augumentation with ARM in misoprostol group $(n=27,60 \%)$ than Foley catheter group $(n=17$, $37.8 \%){ }^{9}$ Similarly, ARM was needed more in PGE2 gel group $(n=20,10 \%)$ than in Foley's catheter group $(n=16,8 \%)$ in study done by Deshmukh et al. ${ }^{17}$ They had used PGE2 gel in the comparision group.

As in this study,Tabowei et al. found lesser complication in Foley catheter group than in Misoprostol group (complication like meconium stained liquor, hypertonus uterine activity, tachysystole and maternal pyrexia). ${ }^{20}$ In another study done by Sujata et al. complication like hypertonus uterine activity, tachysystole were lesser in Foley catheter group as opposed to Misoprostol group. ${ }^{10}$ Tachysystole was seen more in Misoprostole group than in Foley catheter group in the study done by Fox et al. and Oliveira et al. which is comparable to this study. ${ }^{21,22}$ In the study, done by EL-Khayat W et al. and Greybus $\mathrm{M}$ et al. complication like uterine hyperstimulation was seen more in Misoprostol group than Foley catheter group. ${ }^{23,24}$ But complications like hyperstimulation was seen more in Foley catheter group than Misoprostol group in the study done by Jozwiak et al. ${ }^{25}$ They had used PGE2 $10 \mathrm{mg}$ in the comparison group.

\section{CONCLUSIONS}

Post ripening mean Bishop's score was significantly better in Foley catheter group as compared to Misoprostol. The induction to labour interval, induction to delivery interval and labour to delivery interval were less in Foley catheter than Misoprostol which was not statistically significant. Although augmentation of labour was needed more in Foley catheter group than in Misoprostol group, complication of labour were observed less in Foley catheter than Misoprostol group.

\section{ACKNOWLEDGEMENT}

This is to acknowledge my teacher Prof Dr Gehanath Baral and my colleague Dr Rijuta Joshi Jha for assisting me to prepare this manuscript.

\section{REFERENCES}

1. Konar HL, editor. A textbook of obstetrics including perinatology and contraception. 7th ed. Kolkata: New Central Book Agency (P) Ltd; 2011.

2. Cunningham F, Leveno K, Steven L, Hauth J, Rouse D, Spong C, editors. Williams Obstetrics. 23rd ed. New York: McGraw Hill; 2010.

3. Berghella V, Baxter JK, Chauhan SP. Evidence-based labor and delivery management. Am J Obstet Gynecol. 2008;199(5):445-54.

4. Bishop EH. Pelvic Scoring for elective induction. Obstet Gynecol.1964;24:266-8.

5. Hill JB, Thigpen BD, Bofill JA, Magann E, Moore LE, Martin JN Jr. A randomized clinical trial comparing vaginal misoprostol versus cervical Foley plus oral misoprostol for cervical ripening and labor induction. Am J Perinatol. 2009;26(1):33-8

6. Adeniji AO, Olayemi O, Odukogbe AA, Aimakhu CO, Oladokun A, Akindele FO, et al. Comparison of changes in pre-induction cervical factors' scores following ripening with transcervical foley catheter and intravaginal misoprostol. Afr J Med Med Sci. 2005;34(4):377-82

7. Jindal P, Gill B, Tirath B. A comparison of vaginal misoprosto versus foley catheter with oxytocin for induction of labor. J Obstet Gynecol India. 2007;57(1):42-7.

8. Kashanian M, Nazemi M, Malakzadegan A. Comparison of $30-\mathrm{mL}$ and $80-\mathrm{mL}$ foley catheter balloons and oxytocin for preinduction cervical ripening. Int J Gynaecol Obstet. 2009; 105(2):174-5
9. Ferdous J, Khanam NN, Begum MR, Akhtar S. Cervical Ripening: Comparative study between intracervical balooning by foley's catheter and intracervical misoprostol tablet. Journal of Bangladesh College of Physicians and Surgeons. 2009;27(1):5-12

10. Sujata, Iqbal B, Das V, Agarwal A, Singh R. Evaluation of non-pharmacology method-transcervical foley catheter to intravaginal misoprostol and prostaglandin E2 gel for preinduction cervical ripening. Biomedical Research. $2012 ; 23(2): 247-52$

11. Owolabi AT, Kuti O, Ogunlola IO. Randomised trial of intravaginal misoprostol and intracervical Foley catheter for cervical ripening and induction of labour. J Obstet Gynaecol. $2005 ; 25(6): 565-8$

12. Thakur A, Uprety D, Yadav P, Dahal P, Thakur D. Randomized clinical trial comparing the efficacy of vaginally misoprostol and foley catheter for cervical ripening and induction of labour. Health Renaissance. 2011;9(2):88-90.

13. Fatemeh VR, Sedigheh A, Marzieh G, Maliheh HM, Mohamd HM, Farnoush F, et al. Comparison of Vaginal Misoprostol with Foley Catheter for Cervical Ripening and Induction of Labor. Iran J Pharm Res. 2011;10(1):149-54.

14. Fekrat M, Kashanian M, Alavi SMH, Ali Nejad S. Comparison of 3 techniques for cervical ripening and induction of labor with vaginal misoprostol and foley catheter and combination of these two methods. J Fertility Infertility. 2007;8:149-54

15. Sciscione AC, Nguyen L, Manley J, Pollock M, Maas B Colmorgen G. A randomized comparison of transcervical Foley catheter to intravaginal misoprostol for preinduction cervical ripening. Obstet Gynecol. 2001;97(4):603-7. 
16. Niromanesh S, Mosavi-Jarrahi A, Samkhaniani F. Intracervical Foley catheter balloon vs. prostaglandin in preinduction cervical ripening. Int J Gynaecol Obstet. 2003;81(1):23-7.

17. Deshmukh VL, Yelikar KA, Deshmukh AB. Comparative study of intra-cervical foley catheter and gel for pre-induction ripening. J Obstet Gynaecol India. 2011;61(4):418-21.

18. Afolabi BB, Oyeneyin OL, Ogedengbe OK. Intra-vaginal misoprostol versus foley catheter for cervical ripening and induction of labor. Int J Gynaecol Obstet. 2005;89:263-7.

19. Culver J, Strauss RA, Brody S, Dorman K, Timlin S, McMahon MJ. A randomized trial comparing vaginal misoprostol versus Foley catheter with concurrent oxytocin for labor induction in nulliparous women. Am J Perinatol. 2004;21(3):139-46.

20. Tabowei TO, Oboro VO. Low dose intravaginal misoprostol versus intracervical balloon catheter for pre-induction cervical ripening. East Afr Med J. 2003;80(2):91-4.

21. Fox NS, Saltzman DH, Roman AS, Klauser CK, Moshier E, Rebarber A. Intravaginal misoprostol versus Foley catheter for labour induction: a meta-analysis. BJOG. 2011;118(6):64754
22. Oliveira MV, Oberst PV, Leite GK, Aguemi A, Kenj G, Leme VD, et al. Cervical Foley catheter versus vaginal misoprostol for cervical ripening and induction of labor: a randomized clinical trial. Rev Bras Ginecol Obstet. 2010;32(7):346-51.

23. El-Khayat W, Alelaiw H, El-kateb A, Elsemary A. Comparing vaginal misoprostol versus Foley catheter plus vaginal isosorbide mononitrate for labor induction. J Matern Fetal Neonatal Med. 2016;29(3):487-92.

24. Greybush M, Singleton C, Atlas RO, Balducci J, Rust OA Preinduction cervical ripening techniques compared. J Reprod Med. 2001;46(1):11-7.

25. Jozwiak M, OudeRengerink K, Ten Eikelder ML, Van Pampus MG, Dijksterhuis MG, de Graaf IM, et al. Foley catheter or prostaglandin E2 inserts for induction of labour at term: an open-label randomized controlled trial (PROBAAT-P trial) and systematic review of literature. Eur J Obstet Gynecol Reprod Biol. 2013;170(1):137-45. 